\title{
PROTOCOL FOR TREATING ACUTE INFECTIONS IN CASES OF TOTAL KNEE ARTHROPLASTY
}

\section{PROTOCOLO DE TRATAMENTO DAS INFECÇÕES AGUDAS NAS ARTROPLASTIAS TOTAIS DO JOELHO}

\author{
Jose Ricardo Pecora ${ }^{1}$, Ana lucia Munhoz lima ${ }^{1}$, Camilo Partezani Helito ${ }^{1}$, Riccardo Gomes Gobbi ${ }^{1}$, Marco Kawamura Demange ${ }^{1}$, \\ GILBERTO LUIS CAMANHO ${ }^{1}$
}

1. Universidade de São Paulo, Faculdade de Medicina, Instituto de Ortopedia e Traumatologia, São Paulo, SP, Brazil.

\section{ABSTRACT}

Objective: To retrospectively evaluate the results after applying a protocol for treating acute infections in cases of total knee arthroplasty and to establish factors predictive of success or failure. Methods: Thirty-two patients who were diagnosed with acute infection of the knee following total arthroplasty between 2004 and 2009 were retrospectively evaluated. Infections following arthroplasty were treated in accordance with the protocol for acute infections following arthroscopy recommended at our institution. Results: With application of a treatment protocol for acute infections following total knee arthroplasty, 26 patients (81.2\%) had good results and $6(18.8 \%)$ had unsatisfactory results. Statistical analysis showed that the variables correlated with a worse prognosis were age $(p=0.038)$ and number of surgical debridement procedures performed ( $p=0.038)$. Conclusion: Our treatment routine was effective for infection. Prosthesis revision was performed in 2 cases when the initial surgical debridement failed to control the infection. Nível de Evidência IV, Série de casos.

Keywords: Arthroplasty, replacement, knee/methods. Arthroplasty, replacement, knee/adverse effects. Infection.

\section{RESUMO}

Objetivos: Avaliar retrospectivamente os resultados da aplicação do protocolo de tratamento das infecções agudas após artroplastia total do joelho e estabelecer fatores preditivos de bons resultados ou falhas. Métodos: Trinta-e-dois pacientes diagnosticados com infecção aguda após artroplastia total do joelho entre 2004 e 2009 foram avaliados. Os casos caracterizados como infecção foram tratados de acordo com o protocolo de tratamento recomendado em nossa instituição. Resultados: Através da aplicação de nosso protocolo para infecções agudas após artroplastia total do joelho, 26 (81,2\%) pacientes tiveram bons resultados e seis (18,8\%) apresentaram resultados insatisfatórios. Após a análise estatística, as variáveis que se correlacionaram com um pior prognostico foram idade $(p=0,038)$ e número de procedimentos cirúrgicos para limpeza realizados $(p=0,038)$. Conclusão: Nosso protocolo de tratamento foi efetivo no controle de infecção após as artroplastias. Revisão da prótese em dois tempos deve ser realizada quando o primeiro desbridamento cirúrgica não for eficaz no controle do quadro infeccioso. Level of evidence IV, case series.

Descritores: Artroplastia do joelho/métodos. Artroplastia do joelho/ efeitos adversos. Infecção.

Citation: Pecora JR, Lima ALM, Helito CP, Gobbi RG, Demange MK, Camanho GL. Protocol for treating acute infections in cases of total knee arthroplasty. Acta Ortop Bras. [online]. 2019;27(1):27-30. Available from URL: http://www.scielo.br/aob.

\section{INTRODUCTION}

Locomotor system disorders are increasingly prevalent worldwide., ${ }^{1,2}$ Chronic joint pain lasting more than 3 months affects about onefourth of the population over 18 years, and the knee is the most commonly affected joint. ${ }^{2}$

Total knee arthroplasty is very popular, but success is not guaranteed. ${ }^{3}$ Mechanical or biological failure can occur, including failure due to infection. , $^{4}$

Infection after total knee arthroplasty occurs in $1-3 \%$ of cases worldwide, and invariably requires lengthy and costly treatment. ${ }^{6-8}$ The estimated annual expenditure for treatment in the USA is USD 300 million; on our service alone, the annual expenditure exceeded USD 90,000 between 2005 and 2006.1,8
The diagnosis of infection after knee arthroplasty must comply with predetermined clinical and laboratory criteria, as pathologic characterization is not always easy, and treatment should follow protocols that consider the type and time of antibiotic use, indications for surgical joint debridement, removal of instrumentation, placement of antibiotic-loaded cement spacers, and prosthesis replacement. ${ }^{9}$

This prospective study evaluated outcomes after application of a treatment protocol for acute infection in total knee arthroplasty and identified factors predictive of success or failure in treatment of infected arthroplasty.

\section{MATERIALS AND METHODS}

The study was approved by the Research Ethics Committee of our institution (CAAE: 05424312.1.0000.0068). We prospectively

All authors declare no potential conflict of interest related to this article.

Study was conducted at the Knee Division, Instituto de Ortopedia e Traumatologia, HC/FMUSP, São Paulo, SP, Brazil.

Correspondence: Camilo Partezani Helito. Rua Dr. Ovídio Pires de Campos, 333, Cerqueira César, São Paulo, São Paulo, Brazil. 05403-010. camilo_helito@yahoo.com.br 
evaluated 32 patients with a diagnosis of acute knee infection after total arthroplasty between 2004 and 2009. Diagnostic criteria for infection included local clinical parameters, such as inflammation around the wound and secretion from the surgical incision, systemic parameters, such as a decline in general condition and fever, and laboratory parameters, such as elevation of leukocyte count, erythrocyte sedimentation rate, and C-reactive protein.

Cases diagnosed as infection following arthroplasty were treated according to the protocol used for acute infections after knee arthroplasty recommended by the institution. ${ }^{9}$

Initial evaluation characterized the infection as superficial or deep. Superficial infections were initially treated only with broad-spectrum antibiotics, and deep infections were treated with surgical debridement in combination with antibiotics.

Infections that did not resolve after surgical debridement underwent prosthesis removal and placement of antibiotic-loaded cement spacers, with subsequent revision 6 weeks after satisfactory control of the infectious process (Figure 1).

Based on the protocol, 8 patients were treated with antibiotics alone, 19 with antibiotics combined with surgical debridement, and 5 with antibiotics, surgical debridement, prosthesis removal, and spacer placement. Patients who had remission of the infectious process with preservation of knee function were considered to have good results, and those without control of the infection or with impairment of function (requiring arthrodesis, resection arthroplasty, or amputation) were considered to have poor results. ${ }^{10}$
We evaluated patient data including age at arthroplasty, presence of clinical comorbidities, body mass index, and number of previous orthopedic surgeries; microbiological data, including results of intraoperative cultures and microbial load; and data related to application of the protocol including the time between arthroplasty and diagnosis of infection and the number of surgical debridements performed.

The data were analyzed and correlated with treatment outcomes. Fisher's exact test was used in statistical analysis for the association between independent variables and outcomes, the Kolmogorov-Smirnov and Mann-Whitney tests were used for the association between quantitative variables and outcomes, and Spearman's correlation was used for the associations between variables.

\section{RESULTS}

Use of the protocol for treatment of acute infections after total knee arthroplasty resulted in 26 (81.2\%) cases with good results and 6 (18.8\%) with poor results. Among those with poor results, 1 died, 2 required amputation, 1 had aseptic loosening, 1 required knee arthrodesis, and 1 received long-term antibiotic therapy.

Twenty-two patients were male and 10 were female. Age ranged from 35 to 83 years, with a mean of 67.4. Twenty-three patients were older than 65 years, and 9 were younger than 65 years.

Ten (31.2\%) patients had no comorbidities. The most prevalent comorbidity was systemic arterial hypertension, in 20 (62.5\%) cases. Three (9.3\%) patients had diabetes mellitus and $3(9.3 \%)$ had rheumatoid arthritis.

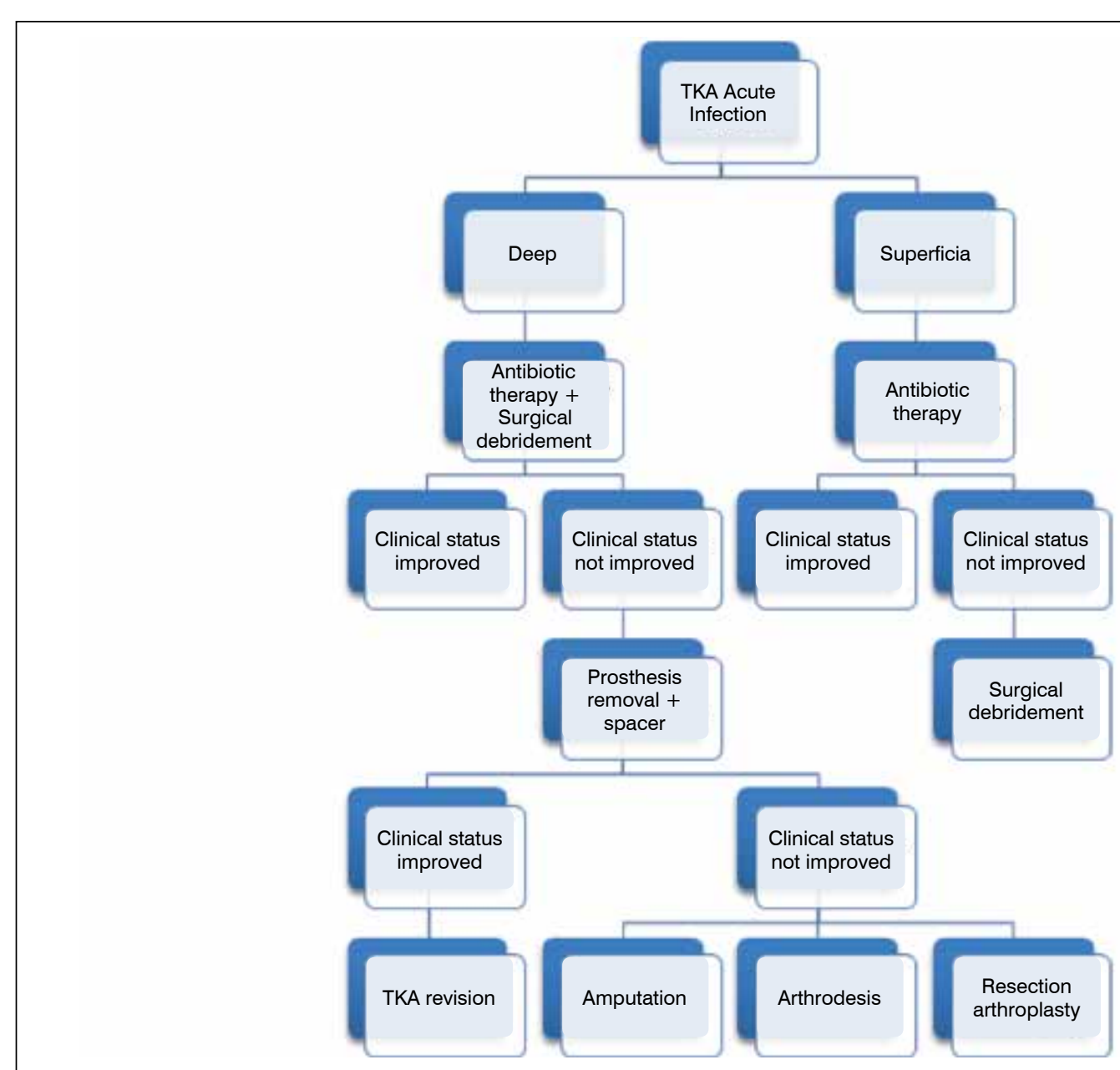

Figure 1. Treatment algorithm in the IOT-HC/FMUSP protocol for acute infection after total knee arthroplasty 
Body mass index (BMI) was determined in only 23 patients, of whom $14(60.8 \%)$ had a BMI greater than 30 , which is considered the cutoff for obesity. Nine patients (39.1\%) had normal weight or were overweight. None of the patients were underweight (BMI less than 18.5).

The number of previous orthopedic surgeries was evaluated in 29 patients. Fourteen (48.3\%) had previously undergone surgery, and arthroplasty was the index procedure in 15 (51.7\%).

In 14 cases (43.7\%), no microorganism was isolated. Staphylococcus aureus was the most prevalent agent, and was isolated in 8 cases (25\%). Other bacteria were isolated in 10 cases (31.3\%). Of the 18 cases (56.2\%) with positive cultures, eleven (34.4\%) had only 1 organism isolated, and 7 (21.9\%) had more than 1 isolated.

Fourteen (43.8\%) patients were diagnosed with infection less than 10 days after arthroplasty and 18 (56.2\%) were diagnosed more than 10 days after surgery.

Sixteen (50\%) underwent only 1 surgical debridement, 7 (21.9\%) did not require a surgical procedure to treat the infection, and 9 (28.1\%) underwent more than 1 procedure (Table 1).

In statistical analysis, the only patient-related variable that was associated with worse prognosis was age. Patients younger than 65 years undergoing arthroplasty had a poor prognosis for remission of the infectious process and preservation of function $(p=0.038)$. Variables such as sex, BMI, diabetes mellitus, rheumatoid arthritis, and the number of previous orthopedic surgeries showed no significant association with outcomes ( $p>0.05)$. There was no statistically significant association between the microbial load and the outcome ( $p>0.05)$. The time elapsed between arthroplasty and diagnosis of infection showed no statistical correlation with a poor outcome $(p=0.365)$. However, patients who underwent more than one surgical debridement were more likely to have a poor outcome $(p=0.038)$

Table 1. Summary of treatment results using the protocol.

\begin{tabular}{|c|c|c|}
\hline & Number & Percentage \\
\hline \multicolumn{3}{|l|}{ Outcome } \\
\hline Good & 26 & $81.2 \%$ \\
\hline Poor & 6 & $18.8 \%$ \\
\hline Mean age (range) & $67.4(35-83)$ & \\
\hline \multicolumn{3}{|l|}{ Sex } \\
\hline Male & 10 & $31.2 \%$ \\
\hline Female & 22 & $68.8 \%$ \\
\hline \multicolumn{3}{|l|}{ Comorbidity } \\
\hline None & 10 & $31.2 \%$ \\
\hline Systemic arterial hypertension & 20 & $62.5 \%$ \\
\hline Rheumatoid arthritis & 3 & $9.3 \%$ \\
\hline Diabetes mellitus & 3 & $9.3 \%$ \\
\hline \multicolumn{3}{|l|}{ BMI (23 patients analyzed) } \\
\hline Greater than 30 & 14 & $60.9 \%$ \\
\hline Less than 30 & 9 & $39.1 \%$ \\
\hline \multicolumn{3}{|c|}{ Previous orthopedic surgery ( 29 patients analyzed) } \\
\hline Yes & 14 & $48.3 \%$ \\
\hline No & 15 & $51.7 \%$ \\
\hline \multicolumn{3}{|l|}{ Infectious agent isolated } \\
\hline No & 14 & $43.7 \%$ \\
\hline S. aureus & 8 & $25 \%$ \\
\hline Others & 10 & $31.3 \%$ \\
\hline \multicolumn{3}{|l|}{ Number of agents isolated } \\
\hline None & 14 & $43.7 \%$ \\
\hline One agent & 11 & $34.4 \%$ \\
\hline More than 1 agent & 7 & $21.9 \%$ \\
\hline \multicolumn{3}{|c|}{ Time between surgery and diagnosis of infection } \\
\hline More than 10 days & 18 & $56.2 \%$ \\
\hline Less than 10 days & 14 & $43.8 \%$ \\
\hline \multicolumn{3}{|l|}{ Number of surgical debridements } \\
\hline None & 7 & $21.9 \%$ \\
\hline One & 16 & $50 \%$ \\
\hline More than 1 & 9 & $28.1 \%$ \\
\hline
\end{tabular}

\section{DISCUSSION}

Most cases of total knee arthroplasty show good results. However, complications can still occur. Infection is one of the most serious complications because of the difficulty of early diagnosis, the lengthy and costly treatment, and the severe sequelae.,11

Infection after arthroplasty can occur due to noncompliance with surgical protocols, surgery itself, or patient-related factors. Some examples are systemic diseases, clinical conditions, and patient living conditions.

Infection following total knee arthroplasty can be direct or hematogenous. Direct infection can occur due to the absence of laminar flow in the surgical environment, inadequate sterilization, incorrect manipulation of surgical material, and excessive number of assistants and others in the surgical environment; variables directly associated with surgical technique, such as prolonged operative time, inadequate hemostasis, and excessive manipulation of soft tissue are also contributory factors. Hematogenous infection can be due to spread from patient foci, such as airway or urinary tract infections, skin ulcers, dental abscesses, or even quiescent bacteria from previous orthopedic surgeries. ${ }^{5}$

Following diagnosis, classification is necessary to determine the appropriate treatment protocol. Superficial infection involves only skin and subcutaneous tissue, and deep infection involves the joint itself; nosocomial infection occurs less than 1 year after arthroplasty and community-acquired infection occurs more than 1 year after surgery; acute infection occurs less than 4 weeks after arthroplasty, before formation of a biofilm, and is otherwise considered chronic. ${ }^{5,9}$ Treatment of infection following arthroplasty aims to preserve the prosthesis, with use of a broad-spectrum systemic antibiotic based on hospital microbial profiles; surgical debridement is used to identify the agent through cultures that guide specific antibiotic therapy. ${ }^{12}$ Many different treatment protocols have been recommended. In the 1970s, the prosthesis was removed, and arthrodesis was attempted. In the 1980s, Freeman recommended one-stage revision. ${ }^{13}$ Two-stage revision was first reported in 1979 and was popularized by Insall in 1983.14,15 The use of a spacer to decrease soft tissue retraction and place antibiotics at the site of infection was introduced by Borden and Gearen ${ }^{16}$ in 1987. Use of a functional spacer, which we believe is the best solution, was introduced in $1995 .{ }^{17}$ Two-stage revision is still limited by the cost of treatment and the limited options for local antibiotic use. ${ }^{18}$

Some treatment recommendations lack consensus in the literature. In acute deep infections, antibiotic therapy alone shows satisfactory results in $23-68 \%$ of cases. Much of this can be explained by the fact that surgical debridement prevents biofilm formation, in contrast to the results from clinical treatment alone. 9,19,20 The number of surgical debridements before prosthesis removal is needed varies. Wasielewski et al. ${ }^{21}$ consider multiple procedures to be beneficial, whereas Sherrell et al. ${ }^{22}$, similar to our conclusions, consider multiple procedures to be undesirable. It is also unclear whether revision after resolution of infection should be performed in 1 or 2 stages. Immediate replacement is undoubtedly less time-consuming and costly, but 2-stage revision has a higher success rate and is more commonly performed. ${ }^{13,23-26}$

We intended to evaluate our findings and correlate the results with patient conditions, microbial load, and application of the protocol. The success rate was significantly higher than that in previous reports. ${ }^{27-29}$ The only patient-related variable associated with a poor outcome was age younger than 65 years; this can be explained by the fact that younger patients usually have more severe joint damage, leading to earlier need for surgery, and resulting in greater surgical trauma. Moreover, younger patients are more active. Earlier surgical indications may be related to comorbidities, such as inflammatory diseases, 
which would also result in a worse prognosis. ${ }^{30}$ Our study examined the correlation between age and other factors that could lead to worse prognosis, such as BMI, diabetes, and rheumatoid arthritis, but no statistical association was found, indicating that younger patients have worse prognosis independent of other variables.

There was no statistical correlation between the microbial load or virulence and worse prognosis. This indicated that correct application of our protocol led to a successful outcome, regardless of the infectious agent.

Another factor predictive of worse prognosis was the number of surgical debridements. The more delayed the surgical debridement after infection, the greater the chance of biofilm formation. Thus, a greater number of surgical debridements favored biofilm formation and delayed a 2-stage prosthesis revision.
Early diagnosis of infection is not always easy, and specific tests are lacking. ${ }^{5,31-33}$ Genetic analysis using messenger RNA is not yet clinically available. ${ }^{34}$ Better characterization of the biofilm and a method to overcome this barrier to remove bacteria adherent to implants are essential to success using different types of treatments. ${ }^{35}$

\section{CONCLUSION}

Analysis of the results following application of our treatment protocol led to highly successful infection control and preservation of knee function. Our outcomes were even better than those in recent prior studies. Younger patients who underwent serial surgical debridements in an effort to maintain the prosthesis had worse outcomes. Two-stage prosthesis revision should be performed when the infection is not successfully controlled after initial debridement.

AUTHORS' CONTRIBUTIONS: Each author contributed individually and significantly to the development of the article. JRP (0000-0003-1621-5252)* and $\mathrm{CPH}(0000-0003-1139-2524)^{*}$ were the main contributors to the writing of the article. JRP, RGG (0000-0002-1715-4343)*, MKD (0000-0003-1999-9478)* and ALML (0000-0002-2396-9880)* performed the surgery, followed the patients, and gathered clinical data. CPH and JRP evaluated the data obtained from the statistical analysis. $\mathrm{CPH}, \mathrm{GLC}(0000-0001-8656-5552)^{*}$, and JRP conducted bibliographic research and article review and contributed to the intellectual concept for the study. ${ }^{*}$ ORCID (Open Researcher and Contributor ID).

\section{REFERENCES}

1. American Academy Orthopaedics Surgeons. The burden of musculoskeletal diseases in the United States. Rosemont: American Academy Orthopaedics Surgeons; 2008.

2. Weinstein SL. 2000-2010: the bone and joint decade. J Bone Joint Surg Am. 2000;82(1):1-3.

3. Kurtz S, Ong K, Lau E, Mowat F, Halpern M. Projections of primary and revision hip and knee arthroplasty in the United States from 2005 to 2030. J Bone Joint Surg Am. 2007;89(4):780-5

4. Pécora JR, Rezende MU, Hernandez AJ, Amatuzzi MM, Pereira CAM, Leivas TP. Análise comparativa das alterações nos fluxos de tensão do joelho nas próteses totais e unicompartimentais cimentadas: estudo experimental em dez cadáveres humanos. Acta Ortop Bras. 2003;11(3):133-44.

5. Pécora JR, Lima ALL, D’Elia. Infecção na artroplastia do joelho. In: Pécora JR, Hernandez AJ, Camanho GL. Artrose do joelho: gênese e soluções. São Paulo; Atheneu; 2010. p. 268-75.

6. Jämsen E, Varonen M, Huhtala H, Lehto MU, Lumio J, Konttinen YT, et al. Incidence of prosthetic joint infections after primary knee arthroplasty. J Arthroplasty. 2010;25(1):87-92.

7. Morrey BF, Westholm F, Schoifet S, Rand JA, Bryan RS. Long-term results of various treatment options for infected total knee arthroplasty. Clin Orthop Relat Res. 1989;(248):120-8.

8. Dal-Paz K, Oliveira PR, Paula AP, Emerick MC, Pécora JR, Lima AL. Economic impact of treatment for surgical site infections in cases of total knee arthroplasty in a tertiary public hospital in Brazil. Braz J Infect Dis. 2010;14(4):356-9.

9. Lima ALLM, Pécora JR, Albuquerque RM, Paula AP, D’Elia CO, Santos ALG, et al. Infecção pós-artroplastia total do joelho: considerações e protocolo de tratamento. Acta Ortop Bras. 2004; 12(4):236-41.

10. Tsukayama DT, Goldberg VM, Kyle R. Diagnosis and management of infection after total knee arthroplasty. J Bone Joint Surg Am. 2003;85-A(Suppl 1):S75-80.

11. Bozic KJ, Kurtz SM, Lau E, Ong K, Chiu V, Vail TP, et al. The epidemiology of revision total knee arthroplasty in the United States. Clin Orthop Relat Res. 2010;468(1):45-51.

12. Lima ALLM. Infecções hospitalares em 46 pacientes submetidos à artroplastia total do quadril [dissertação]. São Paulo: Faculdade de Medicina, Universidade de São Paulo; 1995.

13. Freeman MA, Sudlow RA, Casewell MW, Radcliff SS. The management of infected total knee replacements. J Bone Joint Surg Br. 1985;67(5):764-8.

14. Hovelius $L$, Josefsson $G$. An alternative method for exchange operation of infected arthroplasty. Acta Orthop Scand. 1979;50(1):93-6.

15. Insall JN, Thompson FM, Brause MD. Two-stage reimplantation for the salvage of infected total knee arthroplasty. J Bone Joint Surg Am. 1983;65(8):1087-98.

16. Borden LS, Gearen PF. Infected total knee arthroplasty. A protocol for management. J Arthroplasty. 1987;2(1):27-36.

17. McPherson EJ, Lewonowski K, Dorr LD. Techniques in arthroplasty: use of an articulated PMMA spacer in the infected total knee arthroplasty. J Arthroplasty. 1995;10(1):87-9.

18. Masri BA, Kendall RW, Duncan CP, Beauchamp CP, McGraw RW, Bora B Two-stage exchange arthroplasty using a functional antibiotic-loaded spacer in the treatment of the infected knee replacement: the Vancouver experience.
Semin Arthroplasty. 1994;5(3):122-36.

19. Garner JS. CDC guideline for prevention of surgical wound infections, 1985. Supersedes guideline for prevention of surgical wound infections published in 1982. (Originally published in November 1985). Revised. Infect Control. 1986;7(3):193-200.

20. Tsukayama DT, Wicklund B, Gustilo RB. Suppressive antibiotic therapy in chronic prosthetic joint infections. Orthopedics. 1991;14(8):841-4.

21. Wasielewski RC, Barden RM, Rosenberg AG. Results of different surgical procedures on total knee arthroplasty infections. J Arthroplasty. 1996;11(8):931-8.

22. Sherrell JC, Fehring TK, Odum S, Hansen E, Zmistowski B, Dennos A, et al. The Chitranjan Ranawat Award: fate of two-stage reimplantation after failed irrigation and débridement for periprosthetic knee infection. Clin Orthop Relat Res. 2011;469(1):18-25.

23. Mont MA, Waldman B, Banerjee C, Pacheco IH, Hungerford DS. Multiple irrigation, debridement, and retention of components in infected total knee arthroplasty. J Arthroplasty. 1997;12(4):426-33.

24. Toms AD, Davidson D, Masri BA, Duncan CP. The management of peri-prosthetic infection in total joint arthroplasty. J Bone Joint Surg Br. 2006;88(2):149-55

25. Kotelnicki J, Mitts K. Surgical treatments for patients with an infected total knee arthroplasty. JAAPA. 2009;22(11):40, 43-6.

26. D’Elia CO, Santos ALG, Leonhardt MC, Lima ALLM, Pécora JR, Camanho GL. Tratamento das infecções pós-artroplastia total de joelho: resultados com 2 anos de seguimento. Acta Ortop Bras. 2007;15(3):158-62.

27. Bradbury T, Fehring TK, Taunton M, Hanssen A, Azzam K, Parvizi J, et al. The fate of acute methicillin-resistant Staphylococcus aureus periprosthetic knee infections treated by open debridement and retention of components. J Arthroplasty. 2009;24(6 Suppl):101-4.

28. Parvizi J, Azzam K, Ghanem E, Austin MS, Rothman RH. Periprosthetic infection due to resistant staphylococci: serious problems on the horizon. Clin Orthop Relat Res. 2009;467(7):1732-9.

29. Azzam KA, Seeley M, Ghanem E, Austin MS, Purtill JJ, Parvizi J. Irrigation and debridement in the management of prosthetic joint infection: traditional indications revisited. J Arthroplasty. 2010;25(7):1022-7.

30. Malinzak RA, Ritter MA, Berend ME, Meding JB, Olberding EM, Davis KE. Morbidly obese, diabetic, younger, and unilateral joint arthroplasty patients have elevated total joint arthroplasty infection rates. J Arthroplasty. 2009;24(6 Suppl):84-8

31. erbari E, Mabry T, Tsaras G, Spangehl M, Erwin PJ, Murad MH, et al. Inflamatory blood laboratory levels as markers of prosthetic joint infection: a systematic review and meta-analysis. J Bone Joint Surg Am. 2010;92(11):2102-9.

32. Squire MW, Della Valle CJ, Parvizi J. Preoperative diagnosis of periprosthetic joint infection: role of aspiration. AJR Am J Roentgenol. 2011;196(4):875-9.

33. Deirmengian C, Lonner JH, Booth RE Jr. The Mark Coventry Award: white blood cell gene expression: a new approach toward the study and diagnosis of infection. Clin Orthop Relat Res. 2005;440:38-44.

34. Bergin PF, Doppelt JD, Hamilton WG, Mirick GE, Jones AE, Sritulanondha S, et al. Detection of periprosthetic infections with use of ribosomal RNA-based polymerase chain reaction. J Bone Joint Surg Am. 2010;92(3):654-63.

35. Costerton JW, Stewart PS, Greenberg EP. Bacterial biofilms: a common cause of persistent infections. Science. 1999;284(5418):1318-22. 